\title{
Penggunaan Teknologi Informasi dan Komunikasi dan Implikasinya terhadap Ketangguhan Mata Pencaharian Nelayan
}

\author{
The Use of Information and Communication Technology and \\ Its Implication on The Livelihood Resilience of Fishermen
}

\begin{abstract}
ASIRIN $^{1 *}$, TETI A. ARGO ${ }^{2}$
${ }^{1}$ Program Studi Perencanaan Wilayah dan Kota, Institut Teknologi Sumatera, Jl. Terusan Ryacudu, Desa Way Hui, Kecamatan Jatiagung, Lampung Selatan, Lampung 35365; ${ }^{2}$ Kelompok Keahlian Perencanaan Wilayah dan Perdesaan, Sekolah Arsitektur, Perencanaan dan Pengembangan Kebijakan (SAPPK), Gedung Labtek IXA Lantai II, Institut Teknologi Bandung, Bandung, Jawa Barat 40132; *Penulis korespondensi, e-mail: asirin@itera.ac.id
\end{abstract}

(Diterima: 30 September 2016; Disetujui: 28 November 2016)

\begin{abstract}
The livelihood of fishermen that importantly contributes to regional and rural development in coastal areas has been influenced by climate change and other pressures. On the other hand, the development of Information and Communication Technology (ICT) can be used by fishermen to develop their livelihood resilience. This research aims to explore the use of ICT and its implication to the livelihood resilience of fishermen. This research used qualitative research design using case study in Eretan Wetan Village, Indramayu Regency. The primary data was collected through interview, situational observation, activity observation, and physical artifact observation. Secondary data was also collected as supporting data to describe research context. The analysis was done using open coding to identify themes and to develop the description of those themes. The research found that fishermen that are used to ICT can improve their access to information, enhancing knowledge, enhancing and maintaining network and cooperation, and facilitating participation in the community, and eventually experiencing learning process. By experiencing learning process, fishermen will have the capability to identify information and knowledge, capability to understand challenge and opportunity, and capability to transfer and share knowledge using ICT. Therefore, fishermen will then have the capability to diversifies operational location of fishing and source of information and knowledge which are useful to redevelop access, assets, and self organization capability. These process will be cyclic and accumulate to strengthening their livelihood resilience.
\end{abstract}

Keywords: fishermen, Information and Communication Technology (ICT), livelihood, resilience.

\begin{abstract}
ABSTRAK
Mata pencaharian nelayan yang berkontribusi penting pada pengembangan wilayah dan perdesaan terganggu oleh perubahan iklim dan tekanan lainnya. Di sisi lain, perkembangan Teknologi Informasi dan Komunikasi (TIK) yang maju dapat digunakan nelayan untuk membangun ketangguhan mata pencahariannya. Penelitian ini bertujuan mengeksplorasi penggunaan TIK dan implikasinya terhadap ketangguhan mata pencaharian nelayan. Penelitian ini menggunakan desain penelitian kualitatif dengan strategi studi kasus. Studi kasus pada penelitian ini adalah nelayan di Desa Eretan Wetan, Kabupaten Indramayu. Data primer dikumpulkan dengan cara wawancara, observasi situasi, observasi aktivitas, dan observasi artifak fisik. Data sekunder
\end{abstract}


juga dikumpulkan sebagai data pendukung untuk mendeskrispikan konteks penelitian. Analisis dilakukan dengan pengkodean terbuka (open coding) untuk mengidentifikasi tema-tema dan membangun deskripsi tema-tema tersebut. Penelitian ini mengungkapkan bahwa nelayan yang berulang-ulang dan terbiasa merasakan dengan menggunakan TIK bisa meningkatkan akses terhadap informasi, menambah pengetahuan, menambah dan memelihara jaringan dan kerja sama, dan memfasilitasi partisipasi di dalam komunitas, seiring berjalannya waktu kemudian mengalami proses pembelajaran. Dengan mengalami proses pembelajaran, nelayan kemudian memiliki kemampuan untuk mengidentifikasi informasi dan pengetahuan, kemampuan mengetahui tantangan dan peluang, dan kemampuan mentransfer dan berbagi pengetahuan dengan menggunakan TIK. Dengan begitu, nelayan kemudian mampu mendiversifikasi lokasi operasional menangkap ikan dan mendiversifikasi sumber informasi dan pengetahuan. Selanjutnya, kemampuan mendiversifikasi sumber informasi dan pengetahuan itu berguna kembali membangun akses, aset-aset, dan kemampuan pengorganisasian diri. Begitu seterusnya terjadi suatu siklus proses nelayan menggunakan TIK yang berakumulasi untuk membangun ketangguhan mata pencahariannya.

Kata kunci: Teknologi Informasi dan Komunikasi (TIK), ketangguhan, mata pencaharian, nelayan

\section{PENDAHULUAN ${ }^{1}$}

Mata pencaharian nelayan yang berperan penting pada pengembangan wilayah dan perdesaan terganggu oleh perubahan iklim dan tekanan lainnya. Peran penting nelayan di antaranya adalah mendukung ketahanan pangan, berkontribusi pada pertumbuhan ekonomi wilayah dan pendapatan daerah, serta mendorong kegiatan ekonomi lokal. Namun, perubahan iklim dan tekanan lainnya mengubah pola sumber daya laut dan mengganggu aktivitas nelayan yang pada akhirnya mengancam keberlanjutan sektor ekonomi perikanan laut tangkap, khususnya mata pencaharian nelayan. Sebagai contoh, IPCC (2014) melaporkan bahwa perubahan iklim mengurangi keanekaragaman hayati laut melalui terjadinya pemutihan terumbu karang (coral bleaching) dan asidifikasi (acidification) air laut. Contoh lainnya, bahaya terkait iklim, seperti siklon tropis yang simultan (BMKG, 2011), telah mengganggu aktivitas mata pencaharian, bahkan mengancam keselamatan jiwa. Tekanan lainnya terhadap mata pencaharian nelayan berasal dari pencemaran minyak dan limbah, penggunaan alat tangkap yang tidak ramah lingkungan (illegal fishing),

\footnotetext{
${ }^{1}$ Artikel ini merupakan bagian dari tesis magister (unpublished paper) di Perencanaan Wilayah dan Kota, ITB.
}

eksploitasi ikan berlebih (over fishing), dan alih fungsi guna lahan hutan bakau (Badan Pengelolaan Lingkungan Hidup Daerah Jawa Barat, 2013).

Di sisi lain, perkembangan Teknologi Informasi dan Komunikasi (TIK) yang maju dapat digunakan nelayan untuk membangun mata pencahariannya. Heeks (1999) mendefinisikan TIK sebagai sarana elektronik untuk menangkap, mengolah, menyimpan, dan mengkomunikasikan informasi berbasis digital dan terdiri atas perangkat keras (hardware) komputer, perangkat lunak (software) dan jaringan (networks), termasuk juga teknologi terkait informasi seperti radio, televisi, telefon, koran, dan teknologi terkait informasi lainnya sebagai bagian di dalam sistem TIK. Ketersediaan TIK tersebut seperti Hand Phone (HP), Global Positioning System (GPS), fishfinder, internet beserta sistem informasinya. Dinas Perikanan dan Kelautan Indramayu bekerja sama dengan Balai Penelitian dan Observasi Laut, Kementerian Kelautan dan Perikanan RI (BPOL KKP), Lembaga Penerbangan dan Antariksa Nasional (LAPAN), Badan Meteorologi, Klimatologi dan Geofisika (BMKG), dan koperasi nelayan mengembangkan program sistem Informasi Daerah Penangkapan Ikan (IDPI) untuk mendukung mata pencaharian nelayan (Dinas Perikanan dan Kelautan Kabupaten Indramayu, 
2013; BPOL KKP, 2015). Sistem informasi tersebut termasuk di dalamnya adalah informasi prakiraan cuaca, ketinggian gelombang, kecepatan angin, dan peringatan daerah bahaya pelayaran. Program lainnya yang dikembangkan adalah sosialisasi mitigasi dan adaptasi perubahan iklim untuk nelayan melalui program radio pada tahun 2010/2011. Pelaksanaan program radio tersebut melibatkan The Indonesia Climate Change Trust Fund (ICCTF), BMKG, Lembaga Ilmu Pengetahuan Indonesia (LIPI), Dinas Perikanan dan Kelautan Indramayu, radio komunitas dan komersial, dan beberapa tokoh nelayan (ICCTF, LIPI, dan BMKG, 2012).

Perkembangan dan dukungan TIK tersebut dapat digunakan nelayan untuk menjadi bagian dari strategi membangun ketangguhan mata pencaharian menghadapi perubahan iklim dan tekanan lainnya. TIK berpotensi dapat memfasilitasi nelayan untuk memperbaiki dan memelihara aset-asetnya, untuk mengorganisasi diri (self-organisation), dan belajar (learning). Namun, apakah potensi tersebut benar-benar sudah terwujud pada dimensi-dimensi ketangguhan ${ }^{2}$ mata pencaharian (livelihood resilience) nelayan tersebut. Dengan begitu, penelitian ini diperlukan untuk mengungkap penggunaan TIK oleh nelayan dalam mendukung kesejahteraannya berdasarkan perspektif ketangguhan mata pencaharian. Penelitian terkait penerapan TIK pada konteks ketangguhan sudah dilakukan oleh Ospina dan Heeks (2010) dengan mengembangkan model yang mereka namai "e-resilience" yang memiliki karakteristik dengan kata kunci ketahanan (robustness), skala (scale), kelebihan (redundancy), kecepatan (rapidity), fleksibilitas (flexibility), pengorganisasian diri (self organisation), pembelajaran (learning) (Ospina dan Heeks, 2010), keragaman (diversity), dan

\footnotetext{
${ }^{2}$ Kata "ketangguhan" menjadi terjemahan yang tepat untuk kata "resilience"/"resiliency". Kata "resilient" diterjemahkan menjadi "tangguh". Kata "tangguh" dan "ketangguhan" sudah lazim digunakan sebagai terjemahan dari "resilient" dan "resilience" oleh Badan Nasional Penanggulangan Bencana (BNPB).
}

keadilan (equality) (Heeks dan Ospina, 2013). Namun demikian, Heeks (2014) menyatakan bahwa agenda penelitian hubungan penerapan TIK pada konteks ketangguhan masih belum cukup kuat dan membutuhkan penelitian lanjutan sebagai pondasi dasarnya. Pemahaman lanjutan diperlukan pada bagaimana dampak TIK pada ketangguhan (Heeks dan Ospina, 2013).

Secara etimologi, istilah "resilience" sudah lama digunakan pada berbagai bidang ilmu pengetahuan (Alexander, 2013). Pada bidang geografi manusia, ketangguhan sosial (social resilience) adalah kemampuan sekelompok atau komunitas untuk menanggulangi tekanan dan gangguan eksternal sebagai sebuah hasil dari perubahan sosial, politik, dan lingkungan (Adger, 2000). Sementara itu pada bidang ilmu kajian spesifik sistem sosial-ekologi, ketangguhan sosialekologi (social-ecology resilience) diinterpretasi sebagai sejumlah gangguan yang suatu sistem dapat menyerapnya dan kembali pada kondisi semula; derajat suatu sistem mampu mengorganisasi diri; derajat suatu sistem dapat membangun dan meningkatkan kapasitas untuk belajar dan beradaptasi (Carpenter et al., 2001 dalam Folke, 2006).

Adapun konsep ketangguhan pada konteks sektor perikanan (fisheries sector) sudah dikembangkan oleh beberapa peneliti seperti Adger et al. (2002); Marshall dan Marshall (2007) mengembangkan konsep ketangguhan sosial (social resilience); Allison, et al. (2007) mengembangkan konsep nelayan kecil tangguh (resilient small scale fishery); Ebbin (2009) mengembangkan konsep kelembagaan tangguh (intitutional resilience), dan Van Putten et al. (2013) mengembangkan konsep ketangguhan ekonomi (economic resilience).

Berikut ini beberapa definisi ketangguhan berdasarkan para peneliti yang menggunakan dan mengembangkan konsep ketangguhan dalam konteks perikanan:

a. Adger et al. (2002); Marshall dan Marshall (2007) menyatakan bahwa ketangguhan sosial yaitu kemampuan komunitas atau 
individu untuk menahan dan menyerap guncangan dan tekanan tanpa ada gejolak yang berarti.

b. Allison et al. (2007) menyatakan bahwa ketangguhan nelayan skala kecil adalah kemampuan menyerap guncangan dan reorganisasi sendiri kemampuan dengan tetap berupaya mengurangi kemiskinan.

c. Ebbin (2009) menyatakan bahwa kelembagaan tangguh adalah kemampuan suatu kelembagaan sosial untuk mengendalikan fungsi dan strukturnya.

d. Van Putten et al. (2013) menyatakan bahwa ketangguhan ekonomi pada tingkat individu dicirikan dengan kemampuan menghasilkan kentungan, produk yang beragam, kemampuan mengembalikan modal, dan akses kepada modal.

Adapun konsep ketangguhan mata pencaharian (livelihood resilience) berakar pada pendekatan dan kerangka kerja mata pencaharian berkelanjutan (sustainable livelihood) (Nyamwanza, 2012). Kerangka kerja mata pencaharian berkelanjutan dikembangkan oleh Chambers dan Conway (1992); Scoones (1998; 2009); Ashley dan Carney (1999); Carney (1999; 2002); dan DFID (1999). Marschke dan Berkes (2006) telah mengidentifikasi strategi-strategi masyarakat membangun ketangguhan mata pencaharian meliputi diversifikasi, belajar untuk hidup dengan perubahan dan ketidakpastian, terus belajar dan beradaptasi, menciptakan kesempatan untuk mengorganisasi diri, dan kesejahteraan. Sementara itu, definisi operasional untuk menganalisis ketangguhan mata pencaharian dikembangkan oleh Speranza et al. (2014). Ketangguhan mata pencaharian dikarakteristikkan oleh sekumpulan aset dan strategi untuk memelihara dan meningkatkan aset-aset, untuk mengorganisasi diri dan untuk belajar (Speranza et al., 2014).

Penelitian ini berupaya mengisi kekurangan (gap) penelitian pada topik mengenai kaitan antara TIK dan ketangguhan mata pencaharian nelayan di perdesaan pesisir. Penelitian ini bertujuan mengeksplorasi penggunaan TIK dan implikasinya terhadap ketangguhan mata pencaharian nelayan. Penelitian ini dapat menjadi pelajaran dan saran kebijakan untuk mengembangkan programprogram pembangunan perdesaan nelayan yang memanfaatkan perkembangan TIK. Dengan begitu, program-program dikembangkan untuk membangun kesejahteraan nelayan dan keberlanjutan kelautan berdasarkan perspektif ketangguhan mata pencaharian (livelihood resilience) dalam rangka menghadapi tekanan perubahan iklim dan tekanan perubahan lingkungan lainnya yang kompleks.

\section{METODOLOGI}

\section{Pengumpulan Data}

Penelitian ini mengumpulkan data primer dengan cara wawancara dan observasi. Wawancara merupakan sumber informasi utama pada penelitian ini. Pengamatan dan wawancara dilakukan melalui dua tahap, yaitu tahap awal dan tahap lanjutan. Pengamatan dan wawancara pada tahap awal dilakukan pada tanggal 14, 25, 26, dan 27 Juni 2013. Pengamatan dan wawancara lanjutan dilakukan pada tanggal 26 Maret 2015 dan 7 April 2015. Wawancara dilakukan dengan metode semi terstruktur (semi structured interview). Pertanyaan wawancara pada studi kasus ini bersifat cair daripada kaku. Wawancara dilakukan kepada pelaku usaha nelayan kecil dan nelayan besar. Data hasil wawancara ini digunakan sebagai bahan utama untuk analisis pengalaman-pengalaman dan persepsi-persepsi nelayan. Wawancara juga dilakukan kepada aktor-aktor terkait lainnya meliputi Kepala Bidang Sarana Prasarana Dinas Perikanan dan Kelautan Indramayu, Penyuluh dan Ketua Unit Pelaksana Teknis Dinas (UPTD) Dinas Perikanan dan Kelautan, Manajer Tempat Pelelangan Ikan (TPI) Eretan Wetan, Ketua Koperasi Misaya Mina, dan Pengelola Radio Komunitas Simpati FM. Wawancara kepada pihak-pihak tersebut dilakukan untuk memperkaya dan mengkonfirmasi informasi mengenai pemanfaatan TIK oleh nelayan dan memberikan deskripsi konteks substansi kajian. Selain wawancara, di dalam penelitian ini juga 
dilakukan observasi lapang. Observasi dilakukan oleh peneliti secara langsung untuk mengamati kondisi lapangan, aktivitas penggunaan TIK, dan artifak fisik TIK yang digunakan nelayan.

Di dalam penelitian ini juga dilakukan pengumpulan data sekunder. Penggunaan data sekunder pada studi kasus ini utamanya untuk mendeskrispsikan konteks penelitian, mempertegas dan menambah bukti yang berasal dari sumber lain. Data sekunder meliputi laporan penelitian terdahulu terkait studi kasus ini, data sensus dan data statistik (dari Dinas Perikanan dan Kelautan dan Badan Pusat Statistik), peraturan perundang-undangan terkait kelautan dan perikanan, peta dan diagram, dan data survei yang sudah dikumpulkan sebelumnya oleh lembagalembaga pemerintah pada berbagai tingkatan.

\section{Analisis dan Verifikasi}

Penelitian ini menggunakan kerangka kerja ketangguhan mata pencaharian (livelihood resilience) yang dikembangkan oleh Speranza (2014). Ketangguhan mata pencaharian tersebut dikarakteristikkan oleh sekumpulan aset-aset dan strategi-strategi untuk memelihara dan meningkatkan aset-aset, untuk mengorganisasi diri, pembelajaran dan diversifikasi (Speranza et al. 2014). Adapun definisi operasional dari "implikasi penggunaan TIK terhadap ketangguhan mata pencaharian nelayan" adalah dampak dari suatu aktivitas nelayan menggunakan TIK pada komponen aset, pengorganisasian diri, pembelajaran dan diversifikasi dalam konteks kenelayanan.

Penelitian ini melakukan metode analisis dan upaya verifikasi (reliabilitas dan validitas) kualitatif yang disarankan Creswell (2007; 2010) dan Yin (2009). Proses analisis pada penelitian ini meliputi (1) menyiapkan data mentah (transkripsi, catatan observasi, foto, dan peta, dokumentasi, arsip), Mengolah dan mempersiapkan data untuk dianalisis; (2) membaca keseluruhan data; (3) melakukan open coding data; (4) membuat tema-tema dan deskripsi-deskripsi dari tema-tema tersebut kemudian dinterpretasi dengan tampilan data (tabel, foto, grafik, diagram alir) dan naratif; tampilan data kasus penggunaan TIK dan implikasinya terhadap komponen-komponen karaktersitik ketangguhan disajikan dengan tabel; (5) merumuskan kesimpulan dan rekomendasi. Perumusan kesimpulan dan rekomendasi dilakukan dengan memaknai setiap kasus penggunaan TIK dan rangkaian kasus penggunaan TIK secara menyeluruh. Pemaknaan tersebut diperoleh dari membaca keseluruhan fakta dan bukti-bukti kasus secara berulang-ulang dan mendiskusikan dengan rekan peneliti.

Adapun upaya verifikasi (reliabilitas dan validitas) meliputi mendokumentasikan prosedur penelitian; membuat protokol dan database studi kasus; triangulasi; deskripsi yang kaya dan padat; dan bertanya jawab dengan rekan peneliti. Rincian metodologi dan konteks penelitian ini disajikan secara lengkap pada laporan tesis Asirin (2015). 


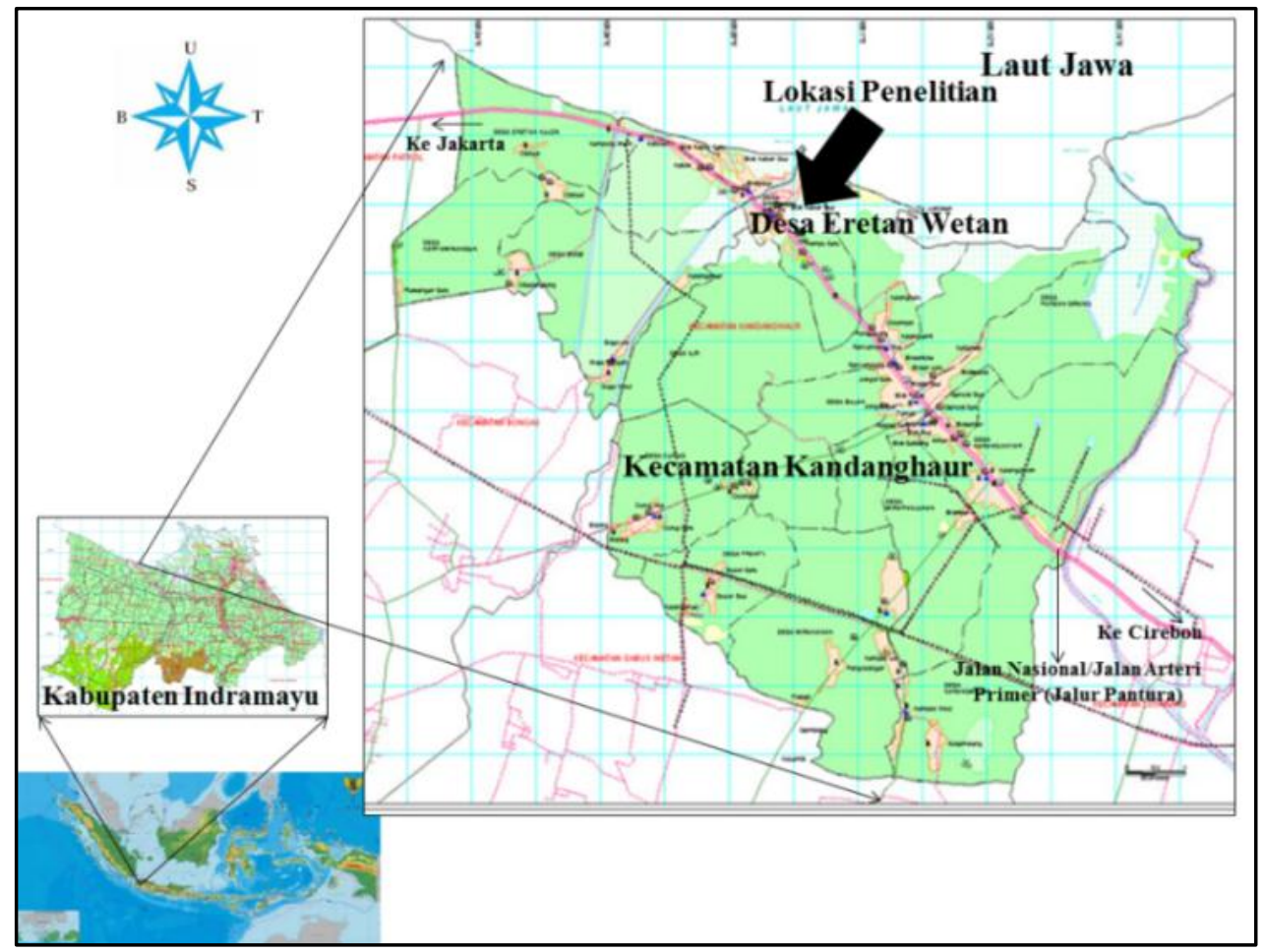

Gambar 1. Peta orientasi lokasi penelitian Sumber: Asirin, 2015.

\section{Lokasi Studi Kasus}

Penelitian ini dilakukan di Desa Eretan Wetan yang merupakan salah satu desa nelayan di Kecamatan Kandanghaur, Kabupaten Indramayu, Provinsi Jawa Barat [lihat Gambar 1]. Pada Desa Eretan Wetan terdapat sungai dan muara sungai. Alur sungai dan muara sungai tersebut dijadikan sebagai jalur keluar masuk kapal dari/ke Pelabuhan Pendaratan Ikan (PPI) sekaligus Tempat Pelelangan Ikan (TPI). Di desa ini juga merupakan tempat lokasi kantor UPTD Dinas Perikanan dan Kelautan, kantor Satuan Polisi Air (Satpol Air), Balai Pelabuhan Perikanan Pantai Provinsi Jawa Barat, Pos Pengamatan Eretan Wetan TNI AL, dan kantor Koperasi Misaya Mina.

\section{HASIL DAN PEMBAHASAN}

Berdasarkan hasil pengumpulan data dan analisis teridentifikasi tema-tema kemudian mendeskripsikannya. Berikut ini adalah tematema beserta deksripsinya.

\section{Penggunaan TIK pada Proses Usaha (Business Process) Nelayan}

Proses usaha nelayan secara garis besar meliputi persiapan, operasional menangkap ikan, dan menjual ikan. Tahap persiapan meliputi kegiatan mengumpulkan personel kapal, menyiapkan kapal beserta kelengkapan peralatannya, dan menyiapkan perbekalan. Tahap operasional menangkap ikan meliputi kegiatan memasang jaring di lokasi penangkapan ikan di laut dan mengumpulkan/ menyimpan hasil tangkapan di tempat yang sudah disediakan di kapal. Tahap menjual ikan meliputi memindahkan ikan dari wadah penyimpanan ikan di kapal ke keranjang ikan kemudian melakukan transaksi penjualan/ pelelangan. Begitu seterusnya proses usaha tersebut sebagai suatu siklus proses usaha. Di dalam proses usaha tersebut, nelayan menggunakan TIK [lihat Gambar 2]. 


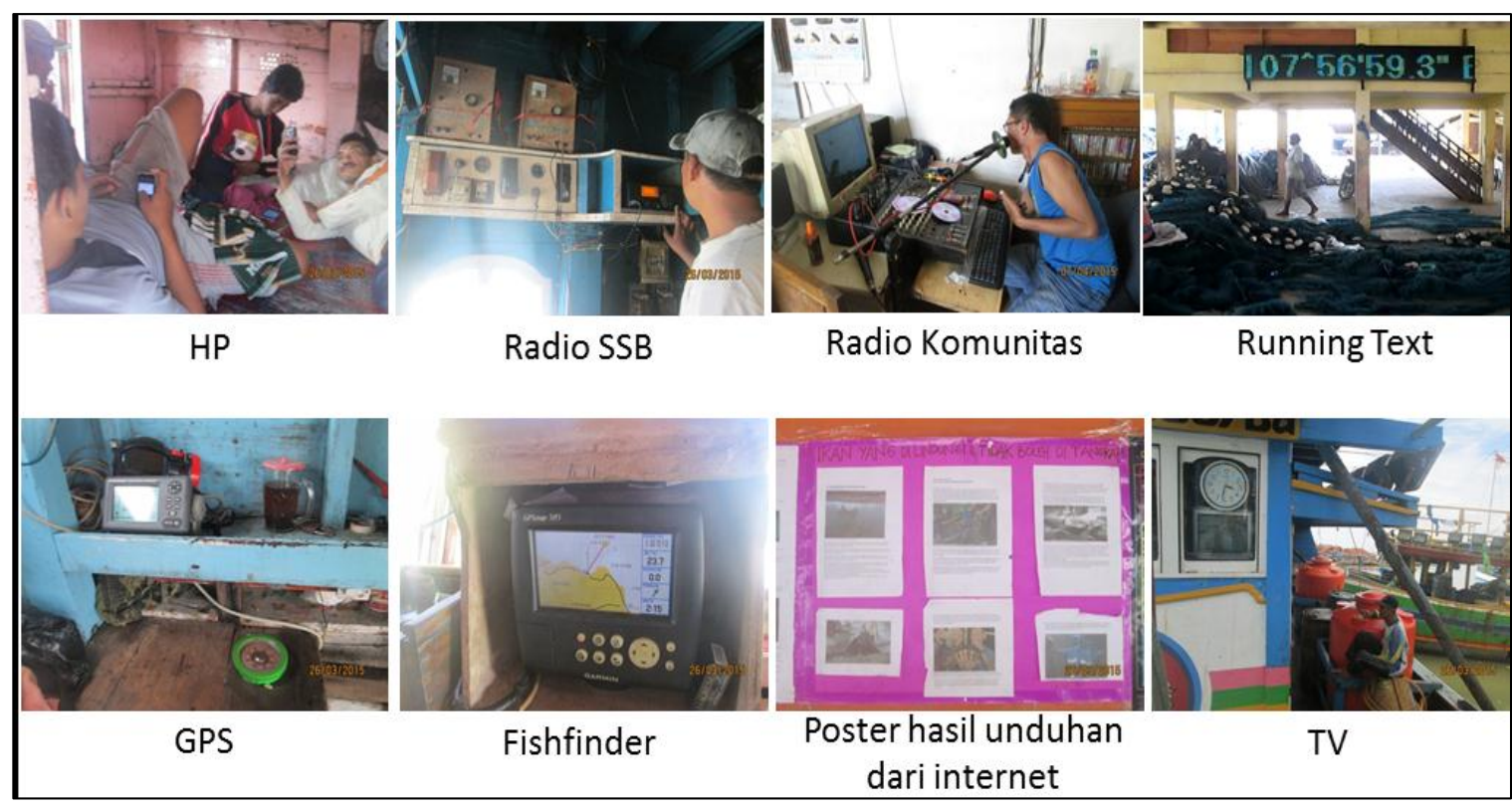

Gambar 2. Jenis-jenis alat TIK yang digunakan nelayan di Desa Eretan Wetan Sumber: Asirin, 2015.

Adapun perilaku penggunaan TIK pada proses usaha nelayan yang teridentifikasi di Desa Eretan Wetan berbeda-beda antara nelayan kecil dan nelayan besar. Nelayan kecil tidak mengakses IDPI karena IDPI hanya diperuntukkan bagi nelayan besar dengan jangkauan operasional menangkap ikan sampai ke perairan Natuna dan Kalimantan. Sementara itu, nelayan besar ada yang mengakses IDPI, ada juga yang tidak mengakses IDPI.

\section{Penggunaan TIK Untuk Mengetahui Perkembangan Kenelayanan}

Pertama, penggunaan TIK untuk mengetahui aturan-aturan dan kebijakan kenelayanan. Sebagai contoh kasus ada nelayan kecil yang sering menonton berita liputan di TV tentang peraturan yang dikeluarkan dan ditegakkan oleh Menteri Susi Pudji Astuti. Dengan menonton berita tersebut, nelayan tersebut mengetahui aturan-aturan yang dikeluarkan KKP mengenai larangan menggunakan alat tangkap ikan yang tidak ramah lingkungan. Nelayan kecil tersebut menyatakan bahwa mendukung aturan tersebut untuk ditegakkan di seluruh Indonesia terutama di Indramayu masih terdapat nelayan menggunakan jaring arad (pukat harimau kecil) yang tidak ramah lingkungan. Nelayan kecil tersebut menyatakan bahwa jaring arad tersebut telah meresahkan dan sudah seharusnya dilarang dan dilakukan penegakan hukumnya. Nelayan tersebut memutuskan tidak menggunakan alat tangkap yang tidak ramah lingkungan. Nelayan kecil tersebut tetap menggunakan alat tangkap yang ramah lingkungan karena mengetahui konsekuensi hukumnya dan menyadari dampak negatifnya.

Selain itu, di Desa Eretan Wetan juga ada perilaku penggunaan internet untuk pembuatan poster sosialisasi jenis/karakteristik ikan yang dilindungi. Di Desa Eretan Wetan, ada juga perilaku penggunaan internet untuk mengunduh naskah peraturan dan kliping berita mengenai jenis/karaktersitik ikan yang dilindungi. Kegiatan tersebut dilakukan oleh pengurus koperasi Misaya Mina. Pengurus koperasi menyatakan bahwa latar belakang penempelan tersebut karena pernah terjadi nelayan yang ditindak dan ditahan secara hukum akibat menangkap ikan pari yang dilindungi. Sejak itu, pengurus koperasi berinisiatif menempel informasi-informasi jenis/karakteristik ikan yang dilindungi. Di Desa Eretan Wetan, teridentifikasi ada nelayan besar menggunakan internet secara tidak langsung. Nelayan besar 
tersebut membaca papan pengumuman yang berisi poster, naskah, dan kliping berita mengenai peraturan jenis/karakteristik ikan yang dilindungi. Dengan membaca papan pengumuman, nelayan besar tersebut menyatakan bahwa informasi tersebut membuatnya mengetahui ciri-ciri ikan yang dilindungi dengan jelas secara visual. Kondisi tersebut menggugah kesadarannya untuk tidak menangkap jenis/karakteristik ikan yang dilindungi. Sebelum ada informasi itu, nelayan besar tersebut menyatakan bahwa tidak mengetahui jenis-jenis ikan yang dilindungi atau yang dilarang untuk ditangkap. Setelah mengetahui informasi itu, nelayan besar tersebut tidak lagi menangkap ikan yang dilindungi atau akan melepaskan kembali ke laut jika tidak sengaja terjaring. Namun demikian, penyebaran poster dan naskah peraturan tersebut terbatas hanya di lokasi Koperasi Misaya Mina di Desa Eretan Wetan. Nelayan kecil tidak mengetahui dan tidak mengakses informasi tersebut.

Bagi nelayan yang menggunakannya, radio SSB laut juga digunakan sebagai sarana komunikasi yang berlangsung dua arah untuk mendapatkan pengetahuan aturan-aturan jenis alat tangkap yang dilarang dan pengetahuan jenis-jenis ikan yang dilindungi. Informasi tersebut diperoleh dengan cara berbagi antar sesama rekan nelayan dan pihak pengguna radio SSB laut lainnya.

Kedua, penggunaan TIK untuk mengetahui isu perubahan iklim dan strategi adaptasinya. Di Desa Eretan Wetan, terdapat nelayan kecil dan nelayan besar yang pernah menggunakan radio komunitas untuk mendapatkan informasi program sosialisasi adaptasi perubahan iklim pada tahun 2010/2011 dari program yang dikembangkan ICCTF, LIPI, dan BMKG bekerja sama dengan Dinas Perikanan dan Kelautan Indramayu dan Radio Komunitas/Komersial Cinde FM serta Radio
Simpat FM Indramayu. Nelayan tersebut menggunakan radio saat di darat, sedangkan saat di laut tidak membawa radio. Nelayan tersebut menggunakan acara talkshow di radio mengenai sosialisasi adaptasi perubahan iklim untuk nelayan. Dengan berpartisipasi pada acara talkshow melalui radio, nelayan kecil tersebut mendapatkan pengetahuan mengenai perubahan iklim dan strategi adaptasi. Nelayan kecil tersebut mendapatkan penjelasan pengetahuan mengenai usaha tambak yang tahan terhadap perubahan cuaca sebagai suatu upaya diversifikasi mata pencaharian. Program tersebut tidak dilaksanakan terus-menerus, hanya pada tahun 2010 dan 2011.

Ketiga, penggunaan TIK untuk mengetahui perkembangan teknik-teknik menangkap ikan dan peralatannya. Bagi nelayan yang menggunakannya, radio SSB laut digunakan sebagai sarana komunikasi yang berlangsung dua arah untuk mendapatkan informasi pengetahuan perkembangan teknik menangkap ikan, pengetahuan perkembangan alat tangkap, pengetahuan perkembangan perlengkapan menangkap ikan, pengetahuan memperbaiki peralatan menangkap ikan, dan pengetahuan/keterampilan terkait usaha kenelayanan lainnya.

\section{Implikasi Penggunaan TIK terhadap Ketangguhan Mata Pencaharian Nelayan}

Berdasarkan uraian di atas, penggunaan TIK telah secara nyata bermanfaat bagi mata pencaharian nelayan. Namun dari manfaatmanfaat tersebut lalu bagaimana kaitannya dengan pengembangan ketangguhan mata pencaharian? Berikut ini implikasi penggunaan TIK terhadap ketangguhan mata pencaharian nelayan yang teridentifikasi dari berbagai bukti kasus nelayan menggunakan TIK di Desa Eretan Wetan [lihat Tabel 1]. 
Tabel 1. Bukti-bukti kasus penggunaan TIK berimplikasi pada ketangguhan mata pencaharian nelayan

\begin{tabular}{|c|c|c|c|}
\hline No. & Dimensi & Implikasi & Bukti Kasus \\
\hline A. & $\begin{array}{l}\text { Endowment dan } \\
\text { akses }\end{array}$ & $\begin{array}{l}\text { Menambah } \\
\text { pengetahuan/ } \\
\text { keterampilan }\end{array}$ & $\begin{array}{l}\text { - Nelayan kecil dan nelayan besar bertambah } \\
\text { pengetahuannya mengenai aturan alat tangkap yang } \\
\text { dilarang dari menonton berita di TV } \\
\text { - Nelayan kecil dan nelayan besar bertambah } \\
\text { pengetahuannya mengenai perubahan iklim dan strategi } \\
\text { adaptasi dengan teknik budidaya ikan di tambak dari } \\
\text { mendengarkan radio komunitas. } \\
\text { - Nelayan besar bertambah pengetahuannya mengenai } \\
\text { jenis/karakteristik ikan yang dilindungi dari membaca } \\
\text { poster dan naskah peraturan hasil unduhan dari } \\
\text { internet. } \\
\text { - Nelayan besar bertambah pengetahuan mengenai } \\
\text { aturan-aturan kenelayanan dan keterampilan teknik- } \\
\text { teknik menangkap ikan yang terbaru dari } \\
\text { berkomunikasi dengan nelayan besar lain } \\
\text { menggunakan radio SSB laut. }\end{array}$ \\
\hline
\end{tabular}

- Nelayan besar bertambah jaringannya dengan nelayan besar lainnya yang belum dikenal dengan

Menambah jaringan

Meningkatkan akses terhadap informasi/ pengetahuan berkomunikasi melalui radio SSB laut, termasuk dalam saling meminta dan memberi bantuan jika ada kerusakan kapal di laut dan informasi lokasi potensi ikan dan cuacanya.

- Nelayan kecil dan nelayan besar mampu mengakses informasi/pengetahuan mengenai aturan alat tangkap yang dilarang dari menonton berita di TV.

- Nelayan kecil dan nelayan besar mampu mengakses informasi/pengetahuan mengenai perubahan iklim dan strategi adaptasi dengan teknik budidaya ikan di tambak dari mendengarkan radio komunitas.

- Nelayan kecil mampu mengakses informasi lokasi potensi ikan dari sesama rekan nelayan kecil di daerah lain menggunakan HP.

- Nelayan besar mampu mengakses informasi daerah penangkapan ikan (IDPI) beserta informasi cuacanya dari membaca SMS HP dan running text, mendengar radio komunitas, dan komunikasi dengan radio SSB laut.

- Nelayan besar mampu mengakses informasi/ pengetahuan mengenai jenis/karakteristik ikan yang dilindungi dari membaca poster dan naskah peraturan hasil unduhan dari internet.

- Nelayan besar mampu mengakses aturan-aturan kenelayanan dan keterampilan teknik-teknik menangkap ikan yang terbaru dari berkomunikasi dengan nelayan besar lain menggunakan radio SSB laut.

- Nelayan besar mampu mengakses informasi lokasi TPI/PPI menggunakan GPS dan mampu mengakses informasi kumpulan ikan dan kondisi dasar laut pada suatu lokasi di laut. 
Tabel 1. (lanjutan)

\begin{tabular}{|c|c|c|c|}
\hline No. & Dimensi & Implikasi & Bukti Kasus \\
\hline \multirow[t]{3}{*}{ B. } & $\begin{array}{l}\text { Pengorganisasian } \\
\text { Diri }\end{array}$ & $\begin{array}{l}\text { Mendapatkan dan } \\
\text { mendiseminasikan } \\
\text { peraturan }\end{array}$ & $\begin{array}{l}\text { - Nelayan besar dan nelayan kecil mendapatkan } \\
\text { informasi peraturan alat tangkap yang dilarang melalui } \\
\text { menonton TV. } \\
\text { - Nelayan besar mendapatkan dan mendiseminasikan } \\
\text { informasi peraturan terkait perikanan melalui } \\
\text { komunikasi dengan sesama nelayan besar pengguna } \\
\text { radio SSB laut. } \\
\text { - Nelayan besar mendapatkan dan mendiseminasikan } \\
\text { peraturan mengenai jenis/karakteristik ikan yang } \\
\text { dilindungi menggunakan poster dan naskah peraturan } \\
\text { hasil unduhan dari internet. }\end{array}$ \\
\hline & & $\begin{array}{l}\text { Kerja sama dan } \\
\text { jaringan }\end{array}$ & $\begin{array}{l}\text { - Nelayan kecil bekerja sama dengan sesama nelayan } \\
\text { kecil lainnya dalam berbagi informasi lokasi potensi } \\
\text { ikan menggunakan HP. } \\
\text { - Nelayan besar bekerja sama dengan sesama nelayan } \\
\text { besar dan pihak-pihak lain pengguna radio SSB laut } \\
\text { dalam berbagi informasi daerah penangkapan ikan } \\
\text { beserta cuacanya, perkembangan teknik menangkap } \\
\text { ikan, dan informasi/pengetahuan lainnya menggunakan } \\
\text { radio SSB laut tersebut. }\end{array}$ \\
\hline & & Partisipasi & $\begin{array}{l}\text { - Nelayan besar dan nelayan kecil terlibat berbagi } \\
\text { pengalaman dan menyampaikan aspirasinya pada acara } \\
\text { talkshow sosialisasi adaptasi perubahan iklim } \\
\text { menggunakan radio komunitas. } \\
\text { - Nelayan besar terlibat di dalam komunitas nelayan } \\
\text { sesama pengguna radio SSB dengan rutin } \\
\text { berkomunikasi menggunakan alat tersebut. }\end{array}$ \\
\hline \multirow[t]{2}{*}{ C. } & Pembelajaran & $\begin{array}{l}\text { Mengetahui } \\
\text { tantangan/peluang }\end{array}$ & $\begin{array}{l}\text { - Nelayan besar dan nelayan kecil mengetahui tantangan } \\
\text { perubahan iklim dengan menggunakan radio } \\
\text { komunitas. } \\
\text { - Nelayan besar mengetahui informasi peluang dari } \\
\text { adanya perkembangan teknik menangkap ikan dan } \\
\text { perkembangan alat tangkap dari berkomunikasi } \\
\text { menggunakan radio SSB laut dengan sesama nelayan } \\
\text { dan pihak lain sesama pengguna alat tersebut saat di } \\
\text { laut. }\end{array}$ \\
\hline & & $\begin{array}{l}\text { Mengidentifikasi } \\
\text { informasi/ } \\
\text { pengetahuan }\end{array}$ & $\begin{array}{l}\text { - Nelayan besar mengidentifikasi harga ikan kualitas } \\
\text { ekspor jenis tertentu dengan cara bertanya kepada } \\
\text { bakul di daerah lain menggunakan HP. } \\
\text { - Nelayan besar dan nelayan kecil mengidentifikasi } \\
\text { informasi potensi ikan dan cuacanya dengan } \\
\text { menanyakan kepada sesama rekan nelayan kecil } \\
\text { menggunakan HP. } \\
\text { - Nelayan besar mengidentifikasi informasi keberadaan } \\
\text { ikan dan kondisi dasar laut dengan menggunakan } \\
\text { fishfinder. }\end{array}$ \\
\hline
\end{tabular}


Tabel 1. (lanjutan)

\begin{tabular}{|c|c|c|c|}
\hline No. & Dimensi & Implikasi & Bukti Kasus \\
\hline & & $\begin{array}{l}\text { Mentransfer dan } \\
\text { berbagi informasi/ } \\
\text { pengetahuan }\end{array}$ & $\begin{array}{l}\text { - Nelayan besar dan nelayan kecil mentransfer/berbagi } \\
\text { informasi lokasi potensi ikan dan informasi cuacanya } \\
\text { kepada sesama rekan nelayan kecil di daerah lain } \\
\text { menggunakan HP. } \\
\text { - Nelayan besar dan nelayan kecil mentransfer/berbagi } \\
\text { pengetahuan dan pengalamannya selama menjadi } \\
\text { nelayan dalam menghadapi perubahan iklim } \\
\text { menggunakan radio komunitas. } \\
\text { - Nelayan besar mentransfer/berbagi informasi daerah } \\
\text { penangkapan ikan dan informasi cuacanya dan } \\
\text { mentransfer/berbagi pengetahuan perkembangan teknik } \\
\text { menangkap ikan dan informasi perkembangan tentang } \\
\text { kenelayanan kekinian menggunakan radio SSB laut. }\end{array}$ \\
\hline \multirow[t]{2}{*}{ D. } & Pendiversifikasian & $\begin{array}{l}\text { Mendiversifikasi } \\
\text { lokasi operasi }\end{array}$ & $\begin{array}{l}\text { - Nelayan kecil memiliki pilihan-pilihan lokasi } \\
\text { menangkap ikan di laut dengan mendapat informasi } \\
\text { potensi ikan dan cuacanya dari sesama rekan nelayan } \\
\text { kecil di daerah lain menggunakan HP. } \\
\text { - Nelayan besar memiliki pilihan-pilihan lokasi } \\
\text { menangkap ikan di laut dengan mendapat informasi } \\
\text { potensi ikan dan cuacanya dari SMS HP, running text, } \\
\text { radio SSB laut dan radio komunitas. }\end{array}$ \\
\hline & & $\begin{array}{l}\text { Mendiversifikasi } \\
\text { sumber informasi/ } \\
\text { pengetahuan }\end{array}$ & $\begin{array}{l}\text { - Nelayan kecil mendapatkan informasi lokasi menangkap } \\
\text { ikan dan cuacanya tidak lagi hanya bersumber dari } \\
\text { pengalaman atau hasil menduga-duga, tetapi juga } \\
\text { bersumber dari sesama rekan nelayan kecil } \\
\text { menggunakan HP. } \\
\text { - Nelayan besar mendapatkan informasi daerah } \\
\text { penangkapan ikan dan cuacanya tidak lagi hanya } \\
\text { bersumber dari pengalaman atau hasil menduga-duga, } \\
\text { tetapi juga dari menggunakan HP, running text, radio } \\
\text { SSB laut. } \\
\text { - Nelayan besar dan kecil mendapatkan informasi aturan } \\
\text { alat tangkap yang dilarang tidak hanya mengandalkan } \\
\text { dari penyuluhan tetapi dari menggunakan TV dengan } \\
\text { cara menonton berita. } \\
\text { - Nelayan besar mendapatkan informasi jenis/karakteristik } \\
\text { ikan yang dilindungi tidak hanya dari mengandalkan } \\
\text { penyuluhan tetapi bisa dari poster dan naskah peraturan } \\
\text { hasil unduhan dari internet. }\end{array}$ \\
\hline
\end{tabular}

Sumber: Asirin, 2015.

\section{KESIMPULAN}

Nelayan yang berulang-ulang menggunakan TIK dan telah terbiasa merasakan bahwa dengan menggunakan TIK tersebut bisa meningkatkan akses terhadap informasi/ pengetahuan/peraturan, menambah pengetahuan, menambah dan memelihara kerja sama/ jaringan, dan memfasilitasi partisipasi di dalam komunitas, lama-lama mengalami proses pembelajaran. Dengan mengalami proses pembelajaran, nelayan kemudian memiliki kemampuan untuk mengidentifikasi pengetahuan, kemampuan mengetahui tantangan/ peluang, dan kemampuan mentransfer/berbagi pengetahuan menggunakan TIK. Dengan begitu, nelayan kemudian mampu mendiversifikasi lokasi operasional menangkap ikan dan mendiversifikasi sumber informasi/ pengetahuan. 
Selanjutnya, kemampuan mendiversifikasi sumber informasi itu berguna kembali membangun endowment, akses dan pengorganisasian diri. Begitu seterusnya menjadi suatu siklus proses nelayan menggunakan TIK untuk membangun ketangguhan mata pencahariannya [lihat Gambar 3].

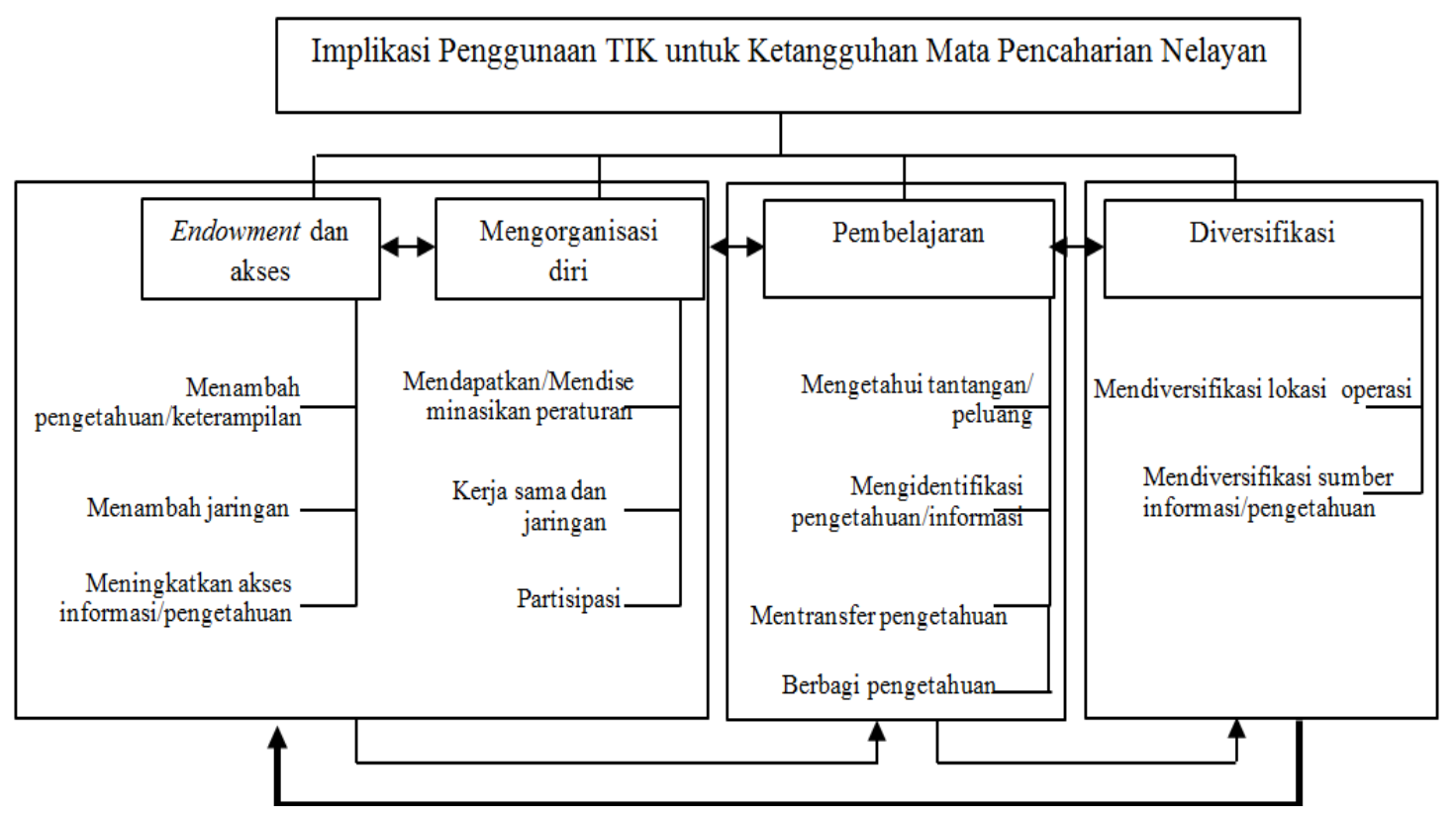

Gambar 3. Implikasi penggunaan TIK untuk ketangguhan mata pencaharian nelayan Sumber: Asirin, 2015.

Penelitian ini membuktikan manfaat TIK untuk membangun ketangguhan mata pencaharian nelayan. Dengan begitu, penelitian ini merekomendasikan perlunya mengembangkan sistem informasi untuk nelayan yang lebih luas dengan target penerima manfaat baik nelayan kecil maupun nelayan besar dan isi yang lebih beragam sesuai kebutuhan nelayan. Sistem informasi yang dikembangkan perlu diperluas tidak terbatas pada daerah penangkapan ikan, cuaca, dan jenis/karakteristik ikan yang dilindungi, tetapi juga informasi harga ikan, akses pembiayaan, strategi-strategi adaptasi perubahan iklim selain usaha tambak, perencanaan keuangan, kewirausahaan, pelestarian ekosistem laut lainnya (seperti hutan bakau, terumbu karang, dan lain-lain), dan keterampilan/pengetahuan lainnya yang sesuai kebutuhan nelayan untuk ketangguhan mata pencaharian nelayan.

Penelitian ini juga merekomendasikan perlunya cara penyampaian informasi yang lebih luas dan mudah diakses nelayan kecil dan nelayan besar baik saat di darat maupun di laut.
Diseminasi informasi perlu melalui mediamedia yang mudah diakses seperti diseminasi poster dan naskah peraturan ke kelompokkelompok nelayan kecil dan tempat-tempat strategis seperti kantor desa, sekolah, masjid, warung, kantor radio komunitas, dan tempattempat strategis lainnya yang merupakan tempat-tempat berkumpul nelayan, tidak hanya di TPI/PPI/Kantor Koperasi. Diseminasi informasi juga perlu menggunakan TIK melalui SMS HP, radio komunitas/komersial, dan TV lokal. Pemerintah daerah juga perlu secara intensif menggunakan radio SSB untuk masuk di dalam forum komunikasi antar nelayan dan membagikan informasi/pengetahuan penting untuk nelayan terkait keberlanjutan sumber daya laut dan adaptasi perubahan iklim.

Penelitian ini juga merekomendasikan perlunya mengembangkan dan melaksanakan program sistem informasi yang terus menerus. Sumber-sumber pembiayaan alternatif dan sumber-sumber daya manusia untuk menjalankan program perlu melibatkan aktoraktor lokal. Aktor-aktor lokal yang perlu 
dilibatkan meliputi koperasi nelayan, radio komunitas/komersial, TV lokal, organisasi komunitas nelayan lokal, koperasi nelayan, dan perusahaan swasta/BUMN melalui program CSR-nya seperti perusahaan-perusahaan telekomunikasi (PT. Telkomsel, dan lainnya), perusahaan transportasi laut, dan PT. Pertamina.

Penelitian ini juga merekomendasikan perlunya mengembangkan kapasitas nelayan dalam menggunakan TIK yang inovatif untuk ketangguhan mata pencaharian nelayan. TIK yang semakin maju dan terjangkau kekinian adalah teknologi internet. Namun, di Desa Eretan Wetan, penggunaan internet masih dilakukan secara tidak langsung. Informasi dari internet dipindahkan dulu ke bentuk poster atau naskah cetak yang kemudian ditempel di papan pengumuman. Padahal, perkembangan internet sudah maju dan menjangkau ke Desa Eretan Wetan. Teknologi internet Web 2.0 kini memungkinkan orang untuk saling berbagi informasi dan pengetahuan. Teknologi tersebut dapat diterapkan pada masyarakat nelayan. Dengan demikian, nelayan generasi muda perlu dilakukan pengembangan penguasaan internet. Penelitian ini merekemondasikan penelitian lanjutan berupa penelitian aksi (research action) pengembangan kapasitas nelayan menggunakan internet untuk ketangguhan mata pencaharian menghadapi perubahan iklim dan tekanan lainnya.

Penelitian ini merekomendasikan

beberapa penelitian lanjutan. Rekomendasi topik penelitian selanjutnya meliputi:

a. Penilaian tingkat ketangguhan mata pencaharian nelayan secara kuantitatif.

b. Eksplorasi strategi-strategi untuk membangun ketangguhan mata pencaharian nelayan.

c. Kajian tata kelola TIK untuk membangun ketangguhan mata pencaharian nelayan.

d. Penelitian tindak inovasi penggunaan TIK dengan menggunakan teknologi internet Web 2.0 untuk ketangguhan mata pencaharian nelayan.

e. Penilaian secara kuantitatif dampak penggunaan TIK untuk ketangguhan mata pencaharian dengan metode eksperimen kepada nelayan dengan melakukan penilaian yang membandingkan antara sebelum dan sesudah nelayan tersebut menggunakan TIK dan/atau sebelum dan sesudah mendapatkan program dukungan sistem informasi perikanan.

f. Evaluasi program kampung nelayan digital kerja sama Kementerian Kelautan dan Perikanan (KKP) dan PT. Telkomsel.

g. Identifikasi kebutuhan informasi, pengetahuan, dan keterampilan lainnya yang dibutuhkan nelayan untuk ketangguhan mata pencahariannya dan mengembangkan program sistem informasi untuk ketangguhan mata pencaharian nelayan dengan metode partisipatif seperti Participatory Rural Appraisal (PRA).

h. Penelitian tindak pengembangan kapasitas penyangga, pembelajaran, pengorganisasian diri, dan pendiversifikasian untuk ketangguhan mata pencaharian nelayan.

\section{Ucapan Terima Kasih}

Tulisan ini merupakan bagian dari penelitian dengan judul "Adaptasi Berbasis Teknologi sebagai Respon terhadap Perubahan Iklim: Studi Kasus Indramayu", yang dibiayai oleh LPPM-Institut Teknologi Bandung. Kami berterima kasih kepada rekan-rekan di Laboratorium Perencanaan Wilayah dan Perdesaan ITB atas bantuannya dalam pengumpulan data dan diskusi serta Prof. Boy Kombaitan dan Ibnu Syabri, Ph.D. atas pembahasan dan masukannya.

\section{DAFTAR PUSTAKA}

Adger, W.N. (2000). Social and ecological resilience: are they related? Progress in Human Geography, 24 (3), 347-364.

Adger, W.N., Kelly, P.M., Winkels, A., Huy, L.Q., \& Locke, C. (2002). Migration, Remittances, Livelihood Trajectories, and Social Resilience. AMBIO: A Journal of the Human Environment, 31 (4), 358-366. 
Alexander, D.E. (2013). Resilience and disaster risk reduction: an etymological journey. Natural Hazards and Earth System Sciences, 13, 2707-2716.

Allison, E.H., Andrew, N.L., \& Oliver, J. (2007). Enhancing the resilience of inland fisheries and aquaculture systems to climate change. SAT eJournal, 4 (1), 1-35.

Ashley, C., \& Carney, D. (1999). Sustainable livelihoods: lessons from early experience. London: Department for International Development.

Asirin. (2015). Penggunaan Teknologi Informasi dan Komunikasi untuk Ketangguhan Mata Pencaharian Nelayan: Studi Kasus Nelayan di Desa Eretan Wetan, Kabupaten Indramayu. Tesis. Perpustakaan Institut Teknologi Bandung.

Badan Pengelolaan Lingkungan Hidup Daerah (BPLHD) Provinsi Jawa Barat. (2013). Status Lingkungan Hidup Jawa Barat Tahun 2013. BPLHD Jawa Barat.

Badan Meteorologi, Klimatologi, dan Geofisika (BMKG). (2011). Pemanasan Global dan Dampaknya terhadap Perubahan CuacaIklim Wilayah Indonesia. Diakses dari: http://wxmod.bppt.go.id/dokumen/materi_se minar/bmkg.pdf pada tanggal 1 Februari 2015.

Balai Penelitian dan Observasi Laut, Kementerian Kelautan dan Perikanan. (2015). Peta PDPI. Diakses dari: http://www.bpol.litbang.kkp.go.id/peta-pdpi pada tanggal 22 Februari 2015.

Carney, D. (2002). Sustainable livelihoods approaches: progress and possibilities for change. London: Department for International Development.

Carney, D., Drinkwater, M., Rusinow, T., Neefjes, K., Wanmali, S., \& Singh, N. (1999). Livelihood approaches compared: a brief comparison of the livelihoods approaches of the UK Department for International Development (DFID), CARE, Oxfam and the UNDP. A brief review of the fundamental principles behind the sustainable livelihood approach of donor agencies. Livelihoods connect. London: Department for International Development.

Chambers, R. \& Conway., G.R. (1992). Sustainable Rural Livelihoods: Practical Concepts for the 21st Century. IDS Discussion Paper 296.
Creswell, J. W. (2007). Qualitative Inquiry and Research Design: Choosing Among Five Approaches (2nd ed.). Thousand Oaks, California: Sage.

Creswell, J. W. (2010). Research Design: Qualitative, Quantitative, and Mixed Methods Approaches, Third Edition. Thousand Oaks, California: Sage.

Department for International Development (DFID), Government of United Kingdom. (1999). Sustainable livelihoods guidance sheets. London: Department for International Development.

Dinas Perikanan dan Kelautan Kabupaten Indramayu. (2013). SMS Center Informasi Daerah Penangkapan Ikan (IDPI) Diskanla Kabupaten Indramayu Bisa Membantu Peningkatan Produksi Hasil Tangkapan Ikan Bagi Nelayan. Dinas Perikanan dan Kelautan Kabupaten Indramayu.

Ebbin, S.A. (2009). Institutional and ethical dimensions of resilience in fishing systems: Perspectives from co-managed fisheries in the Pacific Northwest. Marine Policy, 33, 264270.

Folke, C. (2006). Resilience: the emergence of a perspective for social-ecological Systems analyses. Global Environmental Change, 16 (3), 253-267.

Heeks, R. (1999). Information and communication technology, poverty, and development, Centre for Development Informatics Institute for Development Policy and Management. University of Manchester.

Heeks, R. (2014). Future Priorities for Development Informatics Research from the Post-2015 Development Agenda, Centre for Development Informatics Institute for Development Policy and Management, SEED. University of Manchester.

Heeks, R.B., \& Ospina, A.V. (2013). Understanding Urban Climate Change and Digital Infrastructure Interventions from a Resilience Perspective, Development Informatics. Working Paper 54, Centre for Development Informatics, University of Manchester, UK. Diakses dari http://www.seed.manchester.ac.uk/subjects/id $\mathrm{pm} /$ research/publications/wp/di/ 
Indonesia Climate Change Trust Fund (ICCTF), Lembaga Ilmu Pengetahuan Indonesia (LIPI), dan Badan Meteorologi, Klimatologi, dan Geofisika (BMKG). (2012). Program Acara Radio: Sosialisasi Perubahan Iklim untuk Petani, Nelayan, dan Masyarakat Umum. ICCTF, LIPI, dan BMKG.

Intergovernmental Panel on Climate Change. (2014). Climate Change 2014: Impacts, Adaptation, and Vulnerability. Part A: Global and Sectoral Aspects. Contribution of Working Group II to the Fifth Assessment Report of the Intergovernmental Panel on Climate Change [Field, C.B., V.R. Barros, D.J. Dokken, K.J. Mach, M.D. Mastrandrea, T.E. Bilir, M. Chatterjee, K.L. Ebi, Y.O. Estrada, R.C. Genova, B. Girma, E.S. Kissel, A.N. Levy, S. MacCracken, P.R. Mastrandrea, and L.L. White (eds.)]. Cambridge: Cambridge University Press.

Kementerian Kelautan dan Perikanan. (2009). Undang-Undang Nomor 45 tahun 2009 tentang Perubahan Atas Undang-Undang Nomor 31 Tahun 2004 tentang Perikanan.

Marschke, M. J., \& Berkes, F. (2006). Exploring strategies that build livelihood resilience: a case from Cambodia. Ecology and Society 11
(1),
42.
Diakses
dari: http://www.ecologyandsociety.org/vol11/iss1 /art42/

Marshall, N. A., \& Marshall, P. A. (2007). Conceptualizing and operationalizing social resilience within commercial fisheries in northern Australia. Ecology and Society 12 (1): $1 . \quad$ Diakses dari: http://www.ecologyandsociety.org/vol12/iss1 /art1/.

Nyamwanza, A. M. (2012). Livelihood resilience and adaptive capacity: A critical conceptual review. Jàmbá: Journal of Disaster Risk Studies $\quad 4 \quad$ (1). http://dx.doi. org/10.4102/jamba.v4i1.55.

Ospina, A.V., \& Heeks, R. (2010). Linking ICTs and Climate Change Adaptation: A Conceptual Framework for e-Resilience and $e$ Adaptation. Centre for Development Informatics, University of Manchester, UK. Diakses dari: http://www.niccd.org/sites/default/files/Conc eptualPaper.pdf.

Scoones, I. (1998). Sustainable Rural Livelihoods A Framework For Analysis. IDS Working Paper 72.
Scoones, I. (2009). Livelihoods perspectives and rural development. The Journal of Peasant Studies, 36 (1), 171-196.

Speranza, C. I., Wiesmann, U., dan Rist, S. (2014). An indicator framework for assessing livelihood resilience in the context of socialecological dynamics. Global Environmental Change 28 (2014), 109-119.

Van Putten, I.E., Jennings, S., Frusher, S., Gardner, C., Haward, M., Hobday, A.J., Nursey-Bray, M., Pecl, G., Punt, A., dan Revill, H. (2013). Building blocks of economic resilience to climate change: a south east Australian fisheries example. Regional Environmental Change, Springer-Verlag Berlin Heidelberg.

Yin, R.K. (2009). Case Study Research: Design and Methods, Fourth Edition. Sage Publication. 